\title{
АДМІНІСТРАТИВНО-ПРАВОВЕ ЗАБЕЗПЕЧЕННЯ ПРАВА НА ПРАЦЮ ГРОМАДЯН, ЗАСУДЖЕНИХ ДО ПОЗБАВЛЕННЯ ВОЛІ В УКРАЇНІ
}

\author{
ПОЧАНСЬКА Олена Сергї̈вна - доктор юридичних наук, доцент кафедри \\ правового забезпечення господарської діяльності факультету № 6 Харківського \\ національного університету внутрішніх справ
}

ORCID: https://orcid.org/0000-0003-3953-8660

УДК 342.9

DOI 10.32782/LAW.UA.2020.3.25

\begin{abstract}
Визначено зміст права людини і громадянина на працю, встановлена та охарактеризована його специбіка стосовно правового статусу засудженой особи. Зазначається, щзо в сучасних умовах принципово важливого значення набуває не лише проголошення, бормальне закріплення права на працю для всіх категорій громадян, у тому иислі й засуджених до позбавлення волі, але й можливість його реалізаий, що має забезпечуватися державою та ї інститутами шляхом встановлення відповідних принципів, правил та процедур здійснення цъвого права, закріплення державних гарантій його дотримання та належного захисту.

Проаналізовані особливості сучасного стану адміністративно-правового забезпечення та реалізачій права на прачю громадян, засуджених до позбавлення волі в Украӥні. Наголошується, що принципова зміна у законодавчому закріпленні характеру прачі засуджених зумовила иілу низку відповідних змін як щодо порядку та умов відбування покарання у вигляді позбавлення волі на певний строк у кримінально-виконавчому законодавстві, так $i$ щодо встановлення та дотримання встановлених правил оплати та охорони праиі, техніки безпеки та інших питань правового регулювання та захисту права на прачю громадян, засуджених до позбавлення волі, у нормах кримінально-виконавчого, трудового, адміністративного та інших галузей права.

Встановлено, що, незважаючи на прийняття останнім часом великої кількості нормативно-правових актів, спрямованих на адаптацію норм національного законодавства до міжнародних стандартів щодо захисту прав
\end{abstract}

засуджених, сучасний механізм регулювання та забезпечення права на працю осіб, засуджених до позбавлення волі, потребує значного удосконалення, адже иисленні неузгодженості у нормативному закріпленні изого права, гарантованого Конституцісю Украӥни, істотно знижують рівень його практичної реалізащиї.

Ключові слова: права та свободи, сочіальноекономічні права, право на прачю, адміністративно-правове забезпечення, засуджений до позбавлення волі.

Соціальний характер української держави, закріплений у ст. 3 Конституції України, передбачає належний захист та забезпечення прав і свобод людини і громадянина. Ставлячи за мету забезпечення гідних умов життя для кожної людини, держава визнає за нею комплекс можливостей, пов'язаних із забезпеченням фізичних, матеріальних, духовних та інших соціальних потреб. Однією з найважливіших складових системи і свобод громадян, що створюють юридичні умови для участі людини в соціально-економічному житті, є право на працю. У сучасних умовах принципово важливого значення набуває не лише проголошення, формальне закріплення права на працю для Всіх категорій громадян, у тому числі й засуджених до позбавлення волі, але й можливість його реалізації, що має забезпечуватися державою та їі інститутами шляхом встановлення відповідних принципів, правил та процедур здійснення цього права, закріплення державних гарантій його дотримання та належного захисту. 


\section{Цивільне, підприсмницьке, господарське та трудове право}

\section{Аналіз останніх досліджень} і публікацій

Загальнотеоретичні питання змісту та захисту прав людини розглядалися в працях таких вітчизняних i зарубіжних учених, як В. Авер'янов, Ю. Битяк, А. Глухарьова, О. Зайчук, О. Аукашева, М. Матузов, Ю. Старілов, Ю. Тодика та ін. Права і свободи засуджених, їх дотримання при виконанні кримінального покарання були предметом наукових досліджень Є. Бараша, I. Богатирьова, А. Геля, О. Джужи, В. Льовочкіна, О. Аисодіда, М. Романова, Н. Рябих, А. Степанюка, I. Яковець.

\section{Не вирішені раніше проблеми}

Незважаючи на велику увагу науковців до питань визначення та законодавчого закріплення прав і свобод людини і громадянина в Україні, складність завдання адміністративно-правового забезпечення та встановлення гарантій реалізації права на працю стосовно громадян, засуджених до позбавлення волі, зумовлює необхідність більш детального дослідження даної проблеми.

\section{Мета та завдання статті}

Метою статті є дослідження проблеми забезпечення права на працю громадян, засуджених до позбавлення волі, що передбачає загальну характеристику змісту права на працю, визначення його специфіки стосовно правового статусу засудженого, аналіз особливостей сучасного стану адміністративноправового забезпечення та реалізації права на працю громадян, засуджених до позбавлення волі в Україні.

Наукова новизна дослідження полягає у тому, що стаття $є$ першою науковою працею, у якій проаналізовано особливості адміністративно-правового забезпечення права на працю громадян, засуджених до позбавлення волі в Україні.

\section{Виклад основного матеріалу}

Право на працю є одним з фундаментальних соціальних прав, що передбачає можливість заробляти собі на життя працею, яку особа собі вільно обирає або на яку вільно погоджується [1, ч.1 ст.43]. Право вільного обрання праці або вільного погодження на неї відповідає положенням ст.23 Загальної декларації прав людини [2], у яких встановлюється виключне право самої особи розпоряджатися своїми здібностями до творчої $\mathrm{i}$ продуктивної праці.

Визнаючи та закріплюючи право на працю на рівні Основного Закону, держава гарантує його дотримання та забезпечення умов для повного здійснення цього права шляхом створення рівних можливостей у виборі професії та роду трудової діяльності, а також реалізації програм професійно-технічного навчання, підготовки та перепідготовки кадрів відповідно до суспільних потреб [1, ч.2 ст.43]. Встановлюючи заборону на використання примусової праці, визначену у Міжнародному пакті про громадянські та політичні права [3, ст.8], Конституція зазначає, що не вважається такою військова або альтернативна служба, а також робота чи служба, що виконується особою за вироком суду [1, ч.3 ст.43].

Обов'язком держави також $є$ контроль за організацією та умовами праці. Юридичні гарантії права на працю містить поточне законодавство (норми трудового, адміністративного, кримінального та інших галузей права). Так, зокрема, закріплені в Конституції України права на належні, безпечні і здорові умови праці, на заробітну плату, не нижчу від визначеної законом, а також на своєчасне одержання винагороди за працю [1, ч.4,5 ст.43] захищаються відповідними нормами Кодексу законів про працю України, Кодексу України про адміністративні правопорушення, Кримінального кодексу України, Законів України «Про оплату праці», «Про охорону праці», Наказів Мін'юсту України «Про затвердження Порядку організації виробничої діяльності та залучення засуджених до суспільно корисної праці на підприємствах виправних центрів, виправних та виховних колоній Державної кримінально-виконавчої служби України», «Про затвердження Інструкції про умови праці та заробітну плату засуджених до обмеження волі або позбавлення волі» та ін. Законодавством передбачається й судовий захист права громадян на працю, у тому числі захист 
від незаконного звільнення, вирішення спорів про поновлення на роботі, зміну дати i формулювання причини звільнення та ін.

Право людини і громадянина на працю, закріплене у Конституції України, поширюється й на громадян, засуджених до позбавлення волі. Основний Закон України гарантує, що кожен громадянин (у тому числі й засуджений до позбавлення волі) має право на працю, що включає можливість заробляти собі на життя працею, яку він вільно обирає або на яку вільно погоджується. Використання примусової праці забороняється [1, ч.1,3 ст.43]. Однак до недавнього часу національне кримінальне-виконавче законодавство закріплювало норму, згідно з якою праця в місцях позбавлення волі була не правом, а обов'язком засуджених до позбавлення волі в Україні, які повинні працювати в місцях і на роботах, що визначалися адміністрацією виправних установ. Закон України «Про внесення змін до Кримінально-виконавчого кодексу України щодо адаптації правового статусу засудженого до європейських стандартів» істотним чином змінив правовий статус засуджених осіб, закріпивши у ч.1 ст.8 Кримінально-виконавчого кодексу «право засуджених до позбавлення волі на оплачувану працю, організовану відповідно до вимог законодавства про працю», замінивши в ч.1 ст.118 слова «повинні працювати» на слова «мають право працювати», слова «залучаються до праці» - на слова «залучаються до оплачуваної праці», а також встановивши, що «праця засуджених регламентується Кодексом законів про працю України» [4].

Принципова зміна у законодавчому закріпленні характеру праці засуджених зумовило цілу низку відповідних змін як щодо порядку та умов відбування покарання у вигляді позбавлення волі на певний строк у кримінально-виконавчому законодавстві, так і щодо встановлення та дотримання встановлених правил оплати та охорони праці, техніки безпеки та інших питань правового регулювання та захисту права на працю громадян, засуджених до позбавлення волі, у нормах кримінально-виконавчого, трудового, адміністративного та інших галузей права. Проте слід відзначити й наявність великої кількості норм чинного законодав- ства щодо регулювання та забезпечення права засуджених на працю, які наразі все ще не узгоджені між собою належним чином, суперечать вимогам Основного Закону та сучасних міжнародних стандартів у галузі прав людини. Крім того, через характер самого кримінального покарання це право в певній мірі змінюється, а його складові суттєво обмежуються.

Перш за все, обмеження стосуються вільного вибору роду діяльності засуджених, передбаченого Конституцією України та міжнародними стандартами. Зокрема, Miнімальні стандартні правила поводження 3 в’язнями закріплюють положення, згідно 3 якими в'язні повинні мати можливість працювати за своїм вибором, якщо це сумісно 3 правильним вибором ремесла і вимогами управління та дисципліни в закладі, відповідно до їх фізичних і психічних здібностей $[5$, п.71].

Кодекс законів про працю України гарантує всім працездатним громадянам, які постійно проживають на території України, вільний вибір виду діяльності [6, ст.51], але ст.118 Кримінально-виконавчого кодексу України містить прямо протилежну норму, відповідно до якої засуджені до позбавлення волі залучаються до суспільно корисної праці у місцях і на роботах, безпосередньо визначених адміністрацією пенітенціарного закладу [4, ч.1 ст.118]. Громадяни, засуджені до позбавлення волі, можуть залучатися до оплачуваної праці: у центрах трудової адаптації; у майстернях, підсобних господарствах установ та слідчих ізоляторів; на підприємствах установ виконання покарань; на підприємствах державної або інших форм власності за умови забезпечення їх належної охорони та ізоляції; на роботах з господарського обслуговування установ та слідчих ізоляторів [7, п.1.2]. Неповнолітні, засуджені до позбавлення волі, залучаються до праці лише на підприємствах виховних колоній $[7$, п.3.4].

Стосовно порядку й умов залучення засуджених до праці, ч.1 ст.118 Кримінально-виконавчого кодексу України встановлює, що засуджені до позбавлення волі залучаються до суспільно корисної праці з урахуванням наявних виробничих потужностей, зважаю- 


\section{Цивільне, підприємницьке, господарське та трудове право}

чи при цьому на стать, вік, працездатність, стан здоров'я і спеціальність [4, ч.1 ст.118].

Законодавством встановлено заборону на використання праці засуджених до позбавлення волі щодо окремих видів діяльності [8] та певні обмеження працевикористання залежно від виду й рівня безпеки установи виконання покарань, віку та статі засуджених до позбавлення волі, поведінки засудженого під час відбування кримінального покарання, наявності у засудженого захворювань, а також від інших підстав, передбачених чинним законодавством.

Адміністрація установи виконання покарань зобов'язана створювати умови, що дають змогу засудженим займатися суспільно корисною оплачуваною працею [4, ч.2 ст.118]. Згідно із Законом України «Про Державну кримінально-виконавчу службу України», посадові та службові особи органів і установ виконання покарань зобов'язані організовувати професійно-технічне навчання засуджених та залучати їх до праці [9, п.16 ч.1 ст.18]. Зміст поняття «залучення засуджених до праці» при цьому слід розуміти як унормовану трудовим i кримінально-виконавчим законодавством діяльність адміністрації установи виконання покарань 3 працевлаштування та працевикористання засуджених [10, с.80-81]. Посадові та службові особи установ виконання покарань зобов'язані також забезпечувати додержання вимог законодавства 3 охорони праці, техніки безпеки та виробничої санітарії [9, п.17 ч.1 ст.18].

Згідно $з$ міжнародними стандартами у галузі прав людини та поводження 3 в’язнями, усі заходи та гарантії органів державної влади щодо забезпечення трудових прав засуджених осіб мають відповідати аналогічним заходам, встановленим для осіб, що знаходяться на волі [5, п.71,74]. Проте, якщо за загальною нормою Кодексу законів про працю працівники реалізують право на працю шляхом укладення трудового договору на підприємстві, в установі, організації або 3 фізичною особою [6, ст.2], то за кримінально-виконавчим законодавством засуджені до позбавлення волі залучаються до оплачуваної праці за строковим трудовим договором, що укладається не між засудженим і безпосереднім роботодавцем, а між засудже- ним і установою виконання покарань [4, ч.1 ст.118]. Крім того, як підкреслюють експерти, для ув'язнених, які працюють на підприємствах пенітенціарної системи, механізм врегулювання та захисту трудових та інших соціально-економічних інтересів і прав засуджених взагалі залишається законодавчо не визначеним [11, с.214]. О. Северин, зокрема, зауважує, що за нормами трудового права переведення на іншу роботу на тому ж підприємстві, в установі, організації, а також переведення на роботу на інше підприємство, в установу, організацію або в іншу місцевість є можливим лише за згодою працівника [6, ст.32], то відповідних норм для регулювання переведення на іншу роботу осіб, засуджених до позбавлення волі, не існує [12, с.151]. Також слід погодитись і з тим зауваженням, що у той час, як Кодексом законів про працю передбачено надання громадянам щорічних (основної та додаткової) відпусток із збереженням на їх період місця роботи (посади) і заробітної плати, такі норми у Кримінально-виконавчому кодексі та інших нормативно-правових документах, що регламентують порядок та умови відбування покарання у вигляді позбавлення волі, також відсутні [12, с.151]. Потребують свого уточнення та врегулювання й такі аспекти трудових відносин з особами, засудженими до позбавлення волі, як оплата праці, норми тривалості робочого часу, охорона праці, техніка безпеки i виробничої санітарії, вирішення трудових конфліктів та ін. $з$ урахуванням особливостей роботи засуджених до позбавлення волі та тих обмежень їх у трудових правах, які передбачені чинним законодавством.

Зокрема, важливим елементом забезпечення права на працю громадянина, засудженого до позбавлення волі, є право на гідну оплату його праці. Як справедливо відзначає з цього приводу О. Бублік, суспільно корисна оплачувана праця є не лише джерелом і важливою передумовою фізичного та соціально-психічного розвитку особистості засудженого, але й важливим елементом виправлення і ресоціалізації, дієвим засобом, що зменшує рівень його деградації [10, c.116]. За Европейськими пенітенціарними правилами та Мінімальними стандартними правилами поводження 3 в’язнями, особи, 
засуджені до кримінального покарання у вигляді позбавлення волі, повинні отримувати справедливу винагороду за свою працю [13, с. 1; 5, ч.1 п.76]. Кодекс законів про працю визначає право громадян на працю як забезпечуване державою право на одержання роботи з оплатою праці не нижче встановленого державою мінімального розміру [6, ст.2], а, згідно з Кримінально-виконавчим кодексом України, праця осіб, засуджених до позбавлення волі, оплачується відповідно до ії кількості і якості [4, ч.1 ст.120]. Форми і системи оплати праці, норми праці та розцінки встановлюються нормативно-правовими актами Міністерства юстиції України. Проте аналіз чинного законодавства України з цього питання дозволяє відзначити наявність низки положень, які, за оцінками багатьох експертів, характеризуються складністю і плутаниною та «дають змогу тлумачити їх достатньо довільно, маніпулюючи заробітком засудженого» [14, с.75]. Так, за інформацією Міністерства юстиції України, у сфері управління Міністерства юстиції України перебуває 148 установ, розташованих на території, що контролюється українською владою, у яких станом на початок 2017 р. утримувалося 60 399 осіб. У порівнянні з 2016 р. чисельність таких осіб зменшилася на 9598 осіб (13,7\%). [15, с.251]. При цьому у сфері управління Мiністерства юстиції України знаходиться 138 підприємств Державної кримінально-виконавчої служби України, які у 2016 р. виготовили продукції на загальну суму 488 тис. грн. (2015 р. - 456,3 тис. грн.). Кількість працездатних засуджених осіб в установах виконання покарань станом на 1 січня 2016 р. становила 32095 осіб (у 2015 р. - 32,3 тис. осіб), 3 них працевлаштованими є 16226 осіб (50,6\% від числа працездатних та 30,2\% від загального числа засуджених) (у 2015 р. відповідні показники становили близько 18 тис. осіб). До оплачуваних робіт на виробництві залучено 7330 осіб (2015 р. - 9348 осіб), до робіт 3 господарського обслуговування залучено 1 901 особа (2015 р. - 2242 особи). Разом з тим, лише із 1345 особами укладено строкові трудові договори. Середньомісячна заробітна плата засуджених, які працюють на виробництві, у 2016 р. склала 541 грн. (2015 р. - 424 грн.), осіб, зайнятих на роботах з господар- ського обслуговування, - 1080 грн. (2015 909 грн.). Заборгованість перед засудженими (у тому числі звільненими) у 2016 р. склала 340 тис. грн. (2015 р. - 247 тис. грн.) [16, с.49].

\section{Висновки}

Отже, аналіз норм чинного законодавства України, що стосується регулювання права на працю засуджених осіб, дає можливість констатувати, що, незважаючи на прийняття останнім часом великої кількості нормативно-правових актів, спрямованих на адаптацію норм національного законодавства до міжнародних стандартів щодо захисту прав засуджених, сучасний механізм регулювання та забезпечення права на працю осіб, засуджених до позбавлення волі, потребує значного удосконалення, адже численні неузгодженості у нормативному закріпленні цього права, гарантованого Конституцією України, істотно знижують рівень його практичної реалізації.

\section{Аітература}

1. Конституція України // Відомості Верховної Ради України. - 1996. - № 30. - Ст. 141.

2. Загальна декларація прав людини : Міжнародний документ ООН : від 10.12.1948 р. // Офіційний вісник України. - 2008. -№ 93. - Ст. 3103.

3. Міжнародний пакт про громадянські і політичні права : Міжнародний документ ООН : від 16.12.1966 р. [Електронний ресурс]. - Режим доступу: http://zakon4.rada. gov.ua/ laws/show/995_043.

4. Кримінально-виконавчий кодекс України : Закон України : від 11.07.2003 р., № 1129-IV // Відомості Верховної Ради України. - 2004. - № 3-4. - Ст. 21.

5. Мінімальні стандартні правила поводження з в'язнями : Міжнародний документ ООН : від 30.08.1955 р. [Електронний документ]. - Режим доступу: http://zakon2.rada. gov.ua/laws/show/995_212.

6. Кодекс законів про працю України: Закон України : від 10.12.1971 р., № 322VIII // Відомості Верховної Ради Української PCР. - 1971. - Додаток до № 50. - Ст.375.

7. Про затвердження Інструкції про умови праці та заробітну плату засуджених до обмеження волі або позбавлення волі : 


\section{Цивільне, підприсмницьке, господарське та трудове право}

Наказ Міністерства юстиції України : від 07.03.2013 р., № 396/5 // Офіційний вісник України. - 2013. - № 23. - Ст.798.

8. Про затвердження Правил внутрішнього розпорядку установ виконання покарань : Наказ Мін'юсту України : від 29.12.2014 р., № 2186/5 // Офіційний вісник України. - 2015. - № 4. - Ст. 88.

9. Про Державну кримінально-виконавчу службу України : Закон України : від 23.06.2005 р., № 2713-IV // Відомості Верховної Ради України. - 2005. - № 30. - Ст.409.

10. Бублік О. О. Праця засуджених до позбавлення волі: правова регламентація та кримінально-виконавча практика : дис. ... канд. юрид. наук : 12.00.08 / Бублік Олена Олександрівна ; Класич. приват. ун-т. - Запоріжжя, 2016. - 226 с.

11. Бобко У. П. Про ефективність захисту трудових, соціально-економічних прав та інтересів засуджених - працівників підприємств пенітенціарної системи України // У. П. Бобко // Наук. записки Аьвівського ун-ту бізнесу та права. - 2012. - Вип. 9. - С. 214220.

12. Северин О. О. Праця осіб, засуджених до позбавлення волі: право чи обов'язок, що має допомогти виправленню та ресоціалізації засуджених / О. О. Северин // Вісник Кримінологічної асоціації України. - 2014.№ 7.- С. 147-152.

13. Европейські пенітенціарні правила: Рекомендація Ради Европи R (2006): Міжнародний документ : від 12.02.1987 р. [Електронний ресурс]. - Режим доступу: http:// zakon2.rada.gov.ua/laws/show/994_032.

14. Проблеми забезпечення прав засуджених у кримінально-виконавчій системі України. / В. А. Бадира, О. П. Букалов,А. П. Гель, М. В. Романов, І. С. Яковець; за заг. ред. С. Ю. Захарова. Харківська правозахисна група. - Х. : Права людини, 2011. $368 \mathrm{c}$.

15. Щорічна доповідь Уповноваженого 3 прав людини Уповноваженого Верховної Ради України з прав людини про стан дотримання прав і свобод людини і громадянина в Україні. - К. : Права людини, 2017. - 627 с. [Електронний ресурс]. - Режим доступу: http://www.ombudsman.gov.ua/ua/page/ secretariat $/$ docs $/$ presentations $/$ \&page $=3$.

\section{SUMMARY}

The content of the right of a person and a citizen to work is determined, its specificity in relation to the legal status of a convicted person is established and characterized. It is noted that in modern conditions not only the proclamation, formal consolidation of the right to work for all categories of citizens, including those sentenced to imprisonment, but also the possibility of its implementation, which should be provided by the state and its institutions by establishing appropriate principles, rules and procedures for exercising this right, fixing state guarantees of its observance and proper protection.

The peculiarities of the current state of administrative and legal support and realization of the right to work of citizens sentenced to imprisonment in Ukraine are analyzed. It is noted that the fundamental change in the legislative enshrinement of the nature of the work of convicts has led to a number of relevant changes in the procedure and conditions of imprisonment for a certain period in criminal executive legislation, and in establishing and complying with the rules of payment and labor protection, equipment security and other issues of legal regulation and protection of the right to work of citizens sentenced to imprisonment, in the norms of criminal-executive, labor, administrative and other branches of law.

It is established that despite the recent adoption of a large number of regulations aimed at adapting national legislation to international standards for the protection of convicts' rights, the current mechanism for regulating and ensuring the right to work of persons sentenced to imprisonment needs to be significantly improved. Numerous inconsistencies in the normative consolidation of this right, guaranteed by the Constitution of Ukraine, significantly reduce the level of its practical implementation.

Key words: rights and freedoms, socio-economic rights, right to work, administrative and legal support, sentenced to imprisonment.

16. Моніторинг місць несвободи в Україні: стан реалізації національного превентивного механізму / Спеціальна доповідь Уповноваженого Верховної Ради України з прав людини за 2016 р. - К. : Права людини, 2017. - 145 с. [Електронний ресурс]. - Режим доступу: www.ombudsman.gov.ua/files/Dopovidi/ spec dopov npm 2016 n.pdf. 